\title{
Comparison of Functional Capacity using Primary Percutaneous Coronary Intervention with Pharmacological Therapy on ST Elevation Acute Coronary Syndrome Patients
}

\author{
Andini Nurkusuma Wardhani, ${ }^{1}$ Chaerul Achmad, ${ }^{2}$ Sunaryo B. Sastradimaja ${ }^{3}$ \\ ${ }^{1}$ Faculty of Medicine Universitas Padjadjaran, ${ }^{2}$ Department of Cardiology and Vascular Medicine \\ Faculty of Medicine Universitas Padjadjaran, ${ }^{3}$ Department of Physical Medicine and Rehabilitation, \\ Faculty of Medicine, Universitas Padjadjaran/Dr. Hasan Sadikin General Hospital Bandung
}

\begin{abstract}
Background: Acute Coronary Syndrome (ACS) is a shift manifestations pattern of ischemic myocardium. Revascularization either with Primary Percutaneous Coronary Intervention (PCI) or pharmacological therapy is an optional treatment for ST Elevation Acute Coronary Syndrome (STEACS) patients. The aim of the study was to compare the functional capacity using six-minute walking test on STEACS patients who underwent Primary PCI or pharmacological therapy.

Methods: A cross sectional study was conducted from September to October 2012 to 35 STEACS patients who were treated after two years. The samples were obtained from the list of patients at Dr. Hasan Sadikin General Hospital. Inclusion criteria consisted of patients diagnosed as STEACS, cooperative and not experiencing cognitive disturbance. The exclusion criteria were STEACS patients with unstable angina or myocardial infarct in the last month, stable exertional angina, and pregnant women. The patients underwent 6 minutes walking test,VO2max was measured using theCalahin and Cooper formula, then Metabolic Equation Task (METs) was calculated. Data were analyzed by unpaired T-test.

Results: There were 19 Primary PCI and 16 pharmacological therapy patients. The average of age between thetwo groups was distributed evenly. Most of the STEACS patients were male, had a college/academic degree and were retired. Patients treated with pharmacological therapy had higher average of VO2 max and METs than patients with Primary PCI. There was no significantly differences of METs between those groups $(\mathrm{p}>0.05)$

Conclusions: There were no significantly differences of functional capacity in STEACS patients treated with Primary PCI or Pharmacological therapy. [AMJ.2015;2(1):162-6]
\end{abstract}

Keywords: Functional capacity, Primary Percutaneous Coronary Intervention, six minute walking test, ST Elevation Acute Coronary Syndrome

\section{Introduction}

Cardiovascular diseases (CVDs) are the number one cause of death globally. ${ }^{1}$ The World Health Organization (WHO) has predicted that by the year 2030, approximatelly 23-24 million people will die from CVDs. ${ }^{1,2}$ Coronary Heart Disease (CHD) is one of cardiovascular disease in which there is an imbalance between the supply and demand of the myocardium, and the most common reason for this is caused by atherosclerosis on the coronary arteries. ${ }^{3}$ The CHD itself has been the 5th out of 10 main causes of death in Indonesia with a percentage of $26.7 \% .^{2}$ Acute Coronary Syndrome (ACS) is one out of a large group of CHD patients, the shift of manifestations from myocardial ischemic includes the pattern from angina pectoris which then developed into myocardial infarction accompanied by a spreading, sharp, sudden appearance chest pain with long duration (of about 10 minutes). ${ }^{4}$ Myocardial infarction needs an accurate procedure which is to reopen the tracts of the coronary vessels which are blocked by thrombosis and atherosclerosis, so that the myocardium can be handled before necrosis started to develop. These can be done via pharmacological therapies using fibrinolytic drugs to lyse the obstructing intra-coronary thrombus, so that the circulation can be normalized and limits the spread of the myocardial damage. An alternative procedure

Correspondence: Andini Nurkusuma Wardhani, Faculty of Medicine, Universitas Padjadjaran, Jalan Raya BandungSumedang Km.21, Jatinangor, Sumedang, Indonesia, Phone: +6285697571125 Email: dhiniwardhani30@hotmail.com 
other than fibrinolytic is revascularization throughpercutaneouscoronaryinterventionon the infarct-causing lesions which is referred as Primary Percutaneous Coronary Intervention (Primary PCI). ${ }^{4}$ A medical evaluation on ACS patients is important to determine the stability of the patient's conditions. This medical evaluation can be formed in an examination of the patient's condition interview (to gain subjective information), direct measurement upon physical capacity (objectively through measuring strength, motility, sensation, coordination, balance, functional mobility, as well as cardiovascular capacity), diagnostic test, and functional capacity evaluation (including physical and workload capacity). ${ }^{5}$

The aim of the study was to compare the functional capacity using a six- minute walking test on ST Elevation Acute Coronary Syndrome (STEACS) patients who underwent Primary PCI or pharmacological therapy.

\section{Methods}

A cross sectional study was conducted to 35 STEACS patients who were treated after two years. The samples were obtained from the list of patients at Dr. Hasan Sadikin General Hospital. Inclusion criteria consisted of patients diagnosed as STEACS, who were cooperative and not experiencing cognitive disturbance so that they were able to go through the 6-minute walking test (6MWT), and agreed to participate in the research. The exclusion criteria were STEACS patients with absolute contraindication for the 6MWT, which were unstable angina or myocardial infarct in the last month, stable exertional angina, and pregnant women. Next, the patient's functional capacity was measured employing the 6MWT. The 6MWT is an examination aimed to measure the maximal or submaximal capacity to know the fitness level or aerobic capability of a person using height, weight, age, and gender as well as length of the track as the predictor factors. ${ }^{6,7}$

Steps of the 6MWT performed were: (1) the subject rested for a while when the subject was examined for contraindications, pulse rate, blood pressure, and levels of dyspnea with the Borg Scale which was felt by the subject before examination, (2) the timer was set on to 6 minutes, the subject was then positioned at starting point, and the timer was started whenever the subject was ready, (3) after 6 minutes, the subject was asked to stop, and had their pulse rate and degree of dyspnea examined using the Borg scale for the second time, (4) observed the amount of laps which had been undergone, and the total distance which had been taken, and then recording them in the 6MWT worksheet. ${ }^{6}$

From the result of 6MWT, theV02max of each subject was measured using theCalahin and Cooper formula ${ }^{8,9}$ Functional capacity was described using theMetabolic Equation Task (METs) $)^{8,9}$

Characteristics of the respondents were classified according to age, gender, educational status, occupation, weigh, height, and Body Mass Index (BMI). This research was approved by the Health Research Ethics Committee of the Faculty of Medicine, Universitas Padjadjaran and was conducted from September to October 2012. The data were tested for their normality using Shapiro-Wilk test and analyzed by unpaired T-test.

\section{Results}

Out of sixty-five subjects from the patients list, only 35 patients could be followed up during the study. The distribution of patients were 19 Primary PCI patients and 16 pharmacological therapy patients (Table 1 ).

The average of age between thetwo groups was distributed evenly. Most of the STEACS patients were male, had a college/academic degree and were retired. The two groups had similar average of BMI and walking distance (Table 1).

The average of VO2 max measured by Cooper formula was higher than by Cahalin formula in both groups. Moreover, patients treated with pharmacological therapy had higher average of VO2 max than patients with Primary PCI (Table 2).

Metabolic Equivalent Tasks (METs) as one of theindicators of functional capacity was measured by dividing VO2 max with 3.5 for male and 2.7 for female (Table 3).

This study showed that the result of average of METs in thetwo groups was similar to the result of the average of VO2max. Patients treated with pharmacological therapy had higher average of METs than patients with Primary PCI using either theCahalin or Cooper formula. The result of thestatistical analysis using unpaired T-test, showed thatthere was no significantly differences of METs between those groups ( $\mathrm{p}>0.05)$ 
Table 1 Characteristics of patients with STEACS

\begin{tabular}{|c|c|c|}
\hline \multirow{2}{*}{ Characteristics } & \multicolumn{2}{|c|}{ Intervention } \\
\hline & Primary PCI (n=19) & Pharmacological Therapy $(n=16)$ \\
\hline \multicolumn{3}{|l|}{ Age (years old) } \\
\hline$\leq 57$ & 4 & 5 \\
\hline $58-60$ & 6 & 3 \\
\hline $61-64$ & 4 & 5 \\
\hline$\geq 65$ & 5 & 3 \\
\hline Average Age (standard deviation) & $61.47(7.81)$ & $60.62(6.23)$ \\
\hline \multicolumn{3}{|l|}{ Gender } \\
\hline Male & 13 & 11 \\
\hline Female & 6 & 5 \\
\hline \multicolumn{3}{|l|}{ Education } \\
\hline College/Academy & 12 & 4 \\
\hline High School/Junior High & 6 & 9 \\
\hline Elementary School/None & 1 & 3 \\
\hline \multicolumn{3}{|l|}{ Occupation } \\
\hline Public Servant & 4 & 1 \\
\hline Private & 5 & 3 \\
\hline Household & 1 & 1 \\
\hline Labor & 0 & 2 \\
\hline Retired & 9 & 9 \\
\hline Average Weight (kgBW) & $60.95(8.85)$ & $65.62(11.99)$ \\
\hline Average Height (cm) & $158.58(6.34)$ & $162.19(7.46)$ \\
\hline Average BMI & $24.24(3.39)$ & $24.94(4.11)$ \\
\hline $\begin{array}{l}\text { Average Walk Distance of the Subjects } \\
\text { (meter) }\end{array}$ & 323.37 (77.59) & 333.88 (57.65) \\
\hline
\end{tabular}

\section{Discussions}

The ACS is more common in male than female. Men are more afflicted with ACS attacks compared to women. ${ }^{10-13}$ The similarcondition was also found in this study. Other characteristics of subject in the study was the subject were dominated by patients with age over 57 years. This is inaccordance with the
Framingham Heart Study in Morrow12 which shows that the prevalence of ACS is highest at the age of over 40 years old.

In this study the walking distance of 6MWT of STEACS patients managed with Primary PCI had an average of 323 meter or $66 \%$ of the predicted value of a healthy person. While those with pharmacological therapy in this research had an average of 334 meter or $65 \%$ of the predicted value of a healthy

Table 2 Average of V02 $\mathrm{max}(\mathrm{ml} / \mathrm{kg} / \mathrm{minute})$

\begin{tabular}{lcc}
\hline \multicolumn{1}{c}{ Formula } & Vo2max $(\mathbf{m l} / \mathbf{k g} / \mathbf{m i n u t e})$ Primary PCI & Pharmacological Therapy $(\mathbf{n = 1 6 )}$ \\
\hline Cahalin & $13.68(2.33)$ & $13.99(1.73)$ \\
Cooper & $19.08(5.12)$ & $20.04(3.90)$ \\
\hline
\end{tabular}


Table 3 Average of Metabolic Equivalent Tasks (METs)

\begin{tabular}{lccc}
\hline Formulas & $\begin{array}{c}\text { Primary PCI } \\
(\mathbf{n = 1 9 )}\end{array}$ & $\begin{array}{c}\text { Pharmacological } \\
\text { Therapy (n=16) }\end{array}$ & p value \\
\hline Cahalin & $4.20(0.47)$ & $4.32(0.43)$ & $>0.05$ \\
Cooper & $5.81(1.19)$ & $6.15(0.88)$ & \\
\hline
\end{tabular}

person. According to a study performed by Nirwan ${ }^{11}$ on post-Primary PCI ACS patients, the average is $358 \mathrm{~m}$ or $70 \%$ of the predicted value of a healthy person. The result of average distance of 6MWT in this research was not much different from those of Nirwan's study. The percentage of the predicted value of a healthy person on Primary PCI is higher than the pharmacological therapy is caused by age, height, and weight of various subjects that being an important predictor in the prediction of standard calculation of 6MWT by Enright's formula. ${ }^{14}$

Furthermore, functional capacity is the ability of a person to do his daily activity in accordance with his function. ${ }^{15}$ Functional capacity is often served in the form of METs (Metabolic Equivalents). ${ }^{16}$ METs can be defined as the use of maximal oxygen (VO2 $\max$ in $\mathrm{mL} / \mathrm{kg} /$ minute, the formula of one METs is the same as the oxygen needed at resting seated position, equals to $3.5 \mathrm{~mL} / \mathrm{kg} /$ minute for men, and $2.7 \mathrm{~mL} / \mathrm{kg} /$ minute for women. ${ }^{8,9,14}$ This study showed that there was no significant difference of METs between patients treated by pharmacological therapy and Primary PCI. This finding is in accordance with a previous study performed by Pilote et al. ${ }^{17}$, comparing the quality of life on STEACS patients, with Physical Component Status (PCS) which consists of Physical Function, Role Limitation Due to Physical Health, and Body Pain ${ }^{10}$, who found that both groups were not significantly different in regard of their quality of life on much of the PCS components. This result occured because of the functional capacity after an event of ACS is significantly affected by the ability of the patient to follow his daily activity. ${ }^{17}$

Conclusively, there was no significantly differences of functional capacity in STEACS patients treated with Primary PCI or Pharmacological therapy.

This study had limitations, there is a need to use alarger sample and complete information concluded in themedical records. In this study, only 35 out of 65 patients could participate because of the lack of information about the patient's identity, complete address with RT/
RW, regency, and district, and also phone numbers. To gain a better score on the 6MWT, learning or training effect is needed to let the patients adapt to the test because the learning effect can influence the psychological aspect of the subject against the fear of chest pain and also affect their motivation.14,15,19-20 A standardized and same track are needed to obtain optimal comparison of distance and functional capacity from 6MWT6.

A further study should be conducted using 6MWT several times to measure the improvement of functional capacity time to time.

\section{References}

1. World Health Organization. Fact sheet of cardiovascular diseases (CVDs). Geneva: World Health Organization; 2011 [downloaded in 20 September 2012]; Available at: http://www.who.int/ mediacentre/factsheets/fs317/en/

2. McKay J, Mensah GA, Mendis S, Greenlund $K$. The atlas of heart disease and stroke. Geneva: World Health Organization; 2004 [Cited 2012 September 15]. Available from: http://www.who.int/cardiovascular diseases/resources/atlas/en/

3. Kumar V, Abbas AK, Fausto N, Aster JC, editors. Robbins and Cotran pathologic basis of disease. 8th ed. Philadelphia: Saunders Elsevier; 2010.

4. Naik H, Sabatine MS, Lilly LS. Acute coronary syndrome. In: Lilly LS, editor. Pathophysiology of heart disease. Philadelphia: Lippincott Williams \& Wilkins; 2007. p. 168-96.

5. Tan JC. Work-related musculoskeletal problems. In: Horn SE, editor. Practical manual of physical medicine and rehabilitation: diagnostics, therapeutics, and basic problems. Missouri: Geoff Greenwood; 1998. p. 648-53.

6. American Thoracic Society Committee on Proficiency Standards for Clinical Pulmonary Function Laboratories. 
ATS statement: guidelines for the sixminute walk test. Am J Respir Crit Care. 2002;166(1):111-7

7. American Thoracic Soicety, American College of Chest Physicians. ATS/ ACCP Statement on cardiopulmonary exercise testing. Am J Respir Crit Care. 2003;167(2):211-77.

8. Cahalin L, Pappagianopoulos P, Prevost S, Wain J, Ginns L. The relationship of the 6-min walk test to maximal oxygen consumption in transplant candidates with end-stage lung disease. Chest. 1995;108(2):452-9.

9. Cooper KH. A means of assessing maximal oxygen intake: correlation between field and treadmill testing. JAMA. 1968;203(3):201-4

10. Febrianora M. Kualitas hidup pasien ST elevasi miokard infark yang ditangani dengan primary percutaneous coronary intervention dibandingkan dengan terapi farmakologi di Poliklinik Kardiologi Rumah Sakit Hasan Sadikin Bandung [minorthesis]. Bandung: Universitas Padjadjaran; 2011.

11. Nirwan I. Jarak tempuh uji jalan 6 menit pasca sindrom koroner akut pasca intervensi koroner perkutan pada 1 pembuluh darah [dissertation]. Jakarta: Universitas Indonesia; 2010.

12. Morrow DA, Gersh BJ. Chronic coronary artery disease. In: Libby P, editor: Braunwald's Heard Disease: a textbook of cardiovascular medicine. 8th ed: Philadelphia:Saunders; 2007.

13. Karsiani P. Jarak tempuh pasien pasca infark miokard akut menggunakan uji jalan 6 menit serta faktor-faktor yang mempengaruhi [dissertation]. Jakarta: Universitas Indonesia; 2008.

14. Enright P, Sherill D. Reference equations for six minute walk in healthy adults. Am J Respir Crit Care Med. 1998;158(5 Pt 1):1384-7.

15. Nogueira P, Leal ACM, Pulz C, Nogueira IDB, Filho JAO. Clinical reability of the 6 minute corridor walk test performed within a week of a myocardial infarction. Int Heart J. 2006;47(4):533-40.

16. Quinn E. MET - The standard metabolic equivalent. Sports Medicine; 2007 [updated 29 November 2007; Cited 2012 September 13]; Available from: http://sportsmedicine.about.com/od/ glossary/g/MET.htm.

17. Pilote L, Lauzon C, Huynh T, Dion D, Roux $\mathrm{R}$, Racine N, et al. Quality of life after acute myocardial infartion among patients treated at sites with and without on-site availability of angiography. Arch Intern Med. 2002;162(5):553-9.

18. Ja"rvinen O, Julkunen J, Saarinen T, Laurikka J, Huhtala H, Tarkka MR. Perioperative myocardial infarction has negative impact on health-related quality of life following coronary artery bypass graft surgery. Eur J Cardiothorac Surg. 2004;26:621-7.

19. Reybrouck T. Clinical usefulness and limitations of the 6 minute walk test in patients with cardiovascular or pulmonary disease. Chest. 2003;123:325-7.

20. Fiorina C, Vizzardi E, Lorusso R, Maggio M, De Cicco G, Nodari S, et al. The-6 min walking test early after cardiac surgery-reference values and the effects of rehabilitation programme. Eur J Cardiothorac Surg. 2007;32(5):724-9. 